\title{
LITERASI BARU SEBAGAI BENTUK PENANAMAN NILAI-NILAI KARAKTER DALAM PEMBELAJARAN BAHASA INDONESIA MI DI ERA DISRUPSI
}

\author{
Siti Mutmainah ${ }^{1}$ \\ IAI Al-Falah As-sunniyyah Kencong \\ (imutina@yahoo.com)
}

\begin{abstract}
Disruption is an era of massive changes in all areas of life as a result of a modern technology. The existence of digital technology support has provided many facilities and innovations obtained for education, services have become faster and more efficient and a wide range of connections. The negative impact also arises from the digitalization of the program, for example the role of humans has been largely taken over by robots or automotive machinery which causes more unemployment.

This reality is a big problem, therefore the government needs to answer the challenges of the industrial revolution 4.0, one of which is by providing new literacy reinforcement in the world of education. New literacy is a data on human resources technology or humanism which is a complement to the old literacy, which is read-write-archive.
\end{abstract}

Keywords: disruption era, education, new literacy

\begin{abstract}
Abstrak
Disrupsi merupakan era terjadinya perubahan besar-besaran dalam semua bidang kehidupan sebagai dampak dari teknologi modern. Keberadaan dukungan teknologi digital tersebut banyak memberikan kemudahan dan inovasi yang diperoleh bagi pendidikan, layanan menjadi lebih cepat dan efisien serta jangkauan koneksi yang luas. Dampak negatif juga muncul dari digitalisasi program tersebut, contohnya peran manusia banyak diambil alih oleh robot ataupun mesin otomotif yang mengakibatkan pengangguran semakin banyak.

Kejadian ini menjadi masalah besar, oleh karena itu pemerintah perlu menjawab tantangan revolusi industri 4.0, salah satunya dengan cara memberikan penguatan literasi baru di dunia pendidikan. Literasi baru ialah data teknologi SDM atau humanisme yang merupakan pelengkap dari literasi lama yaitu baca-tulis-arsip.
\end{abstract}

Kata Kunci: era disrupsi, pendidikan, literasi baru

\section{PENDAHULUAN}

Negara Indonesia sekarang sudah memasuki era disrupsi, di mana teknologi informasi telah menjadi basis dalam kehidupan manusia. Disrupsi dalam KBBI artinya hal tercabut

\footnotetext{
${ }^{1}$ Dosen IAI Al-Falah As-Sunniyyah Kencong-Jember
} 


\section{Siti Mutmainah}

dari akarnya. Pengertian era disrupsi itu sendiri adalah era banyaknya perubahan. Perkembangan internet dan teknologi digital yang masif menjadi pemicu pergerakan dan konektivitas manusia dan mesin yang menyebabkan segala hal menjadi tanpa batas. Era ini juga akan mendisrupsi berbagai aktivitas manusia, diantaranya dalam bidang ilmu pengetahuan dan teknologi serta bidang pendidikan.

Era disrupsi juga disebut sebagai era revolusi industri 4.0 yakni suatu era terjadinya perubahan besar-besaran pada semua bidang kehidupan tak terkecuali perubahan juga terjadi pada bidang pendidikan. Pendidikan merupakan aspek yang sangat berperan untuk menyiapkan generasi dalam menghadapi tantangan di era disrupsi. Pendidikan adalah usaha sadar dan terencana untuk mewujudkan suasana belajar dan proses pembelajaran, agar peserta didik secara aktif mengembangkan potensi dirinya untuk memiliki kekuatan spiritual keagamaan, pengendalian diri, kepribadian, kecerdasan akhlak mulia, serta keterampilan yang diperlukan dirinya, masyarakat, bangsa dan negara. ${ }^{2}$

Pengertian tersebut menguatkan bahwa pendidikan nasional berfungsi mengembangkan kemampuan dan membentuk watak serta peradaban bangsa yang bermartabat, dalam rangka mencerdaskan kehidupan bangsa dan bertujuan untuk mengembangkan potensi peserta didik agar menjadi manusia yang beriman dan bertakwa kepada Tuhan Yang Maha Esa, berakhlak mulia, sehat, berilmu, cakap, kreatif, mandiri dan menjadi warga negara yang demokratis serta bertanggung jawab. ${ }^{3}$ Satuan pendidikan harus mampu menyediakan seperangkat rencana dan pengaturan mengenai tujuan isi dan bahan pelajaran serta cara yang digunakan sebagai pedoman penyelenggaraan kegiatan pembelajaran.

Tahun 2016 Kemendikbud mulai menggiatkan gerakan literasi nasional (GLN) dalam membangun budaya literasi pada ranah pendidikan keluarga, sekolah dan masyarakat. Hal ini menjadi bagian implementasi Peraturan Menteri Pendidikan dan Kebudayaan Nomor 23 Tahun 2015 tentang penumbuhan budi pekerti. GLN juga digiatkan pemangku kepentingan pegiat literasi, akademisi, organisasi, profesi dunia usaha, kementerian dan lembaga lain. ${ }^{4}$

\footnotetext{
2 Kemendikbud. Undang-Undang No. 20 Tahun 2003 tentang Sistem Pendidikan Nasional (Jakarta: Kemdikbud, 2003), 2

3 I. Sujadi, Menumbuhkan Karakter Bangsa dengan Mengimplementasikan Mathematics Value dalam Pembelajaran (Pontianak: IKIP PGRI Pontianak, 2017), 14

${ }^{4}$ Ali Ibrahim Ghufran dkk, Peta Jalan Gerakan Literasi Nasional (Jakarta: Kemdikbud, 2017), 7
} 
Literasi Baru Sebagai Bentuk Penanaman...

Pendidik di era disrupsi ini harus menguatkan kemampuan literasi baik dari literasi lama (membaca, menulis, berhitung) dengan literasi baru (data, teknologi, SDM/ humanisme) yang dimulai dari kurikulum, sistem manajemen, model, strategi, dan pendekatan pembelajarannya harus diperkuat dengan keterampilan literasi abad 21. Pada 17 Januari 2018, gagasan literasi baru sudah muncul saat Rapat Kerja Nasional (Rakernas) Kementerian Riset Teknologi dan Pendidikan Tinggi (Kemenristekdikti). Literasi baru yaitu data teknologi dan SDM yang dibentuk untuk menyongsong era disrupsi atau ketercerabutan. Saat ini kalangan akademisi dan peserta didiknya harus menerapkan literasi baru yaitu data, teknologi humanisme. ${ }^{5}$

Literasi tidak hanya sekedar membaca, melainkan kemampuan kompleks dari keempat keterampilan berbahasa yaitu menyimak, mendengarkan, membaca, menulis dan berbicara. Literasi bisa diartikan semua usaha dalam mendapatkan ilmu pengetahuan dan informasi komputer serta menangkal berita bohong dan palsu yang masuk di dalamnya. ${ }^{6}$ Guru diharuskan untuk memahami dan menguasai literasi baru yang menekankan pada pengetahuan berbasis data, teknologi dan humanisme yang bukan sekedar membaca, menulis dan berhitung saja. Di era revolusi 4.0 atau disrupsi ini, pendidikan harus merespon cepat agar tidak tertinggal dengan negara lain.

Tantangan yang harus dihadapi di era disrupsi adalah meningkatkan kualitas Sumber Daya Manusia serta penguatan karakter bangsa. Pendidikan merupakan suatu upaya untuk membangun pengetahuan, sikap dan keterampilan agar generasi berikutnya siap menghadapi tantangan zaman ke depan. Tulisan Ini memberikan penguatan bahwa nilainilai yang dibutuhkan generasi milenial di era disrupsi dapat diperoleh melalui pembelajaran bahasa Indonesia. Pembelajaran online yang dapat diakses di Indonesia sangat berdampak bagi keseluruhan sistem pendidikan. Transformasi dalam bidang penelitian dan pembelajaran bahasa Indonesia diperlukan untuk menjawab tantangan di era disrupsi. Tantangan tersebut yaitu meningkatkan Sumber Daya Manusia yang mampu bersaing secara global, oleh karena itu satuan pendidikan harus mampu menyediakan pedoman pembelajaran demi terselenggaranya tujuan pendidikan tersebut.

\footnotetext{
${ }^{5}$ Ibda Hamidulloh, Penguatan Gernas Baku dalam Keluarga (Opini Satelit Post., 10 April 2018), 2

${ }^{6}$ Farid Ahmadi dan Ibda Hamidulloh, Media Literasi Sekolah Teori dan Praktik (Semarang: CV Pilar Nusantara, 2018), viii

56 | Jurnal Auladuna
} 


\section{Siti Mutmainah}

Bahasa Indonesia merupakan salah satu bidang ilmu yang diajarkan di semua jenjang pendidikan di Indonesia. Sebagai bahasa negara yang sudah banyak digunakan, tentu saja ini menjadi boomerang bagi pendidik atau pengajar bahasa Indonesia. Seringkali siswa menyepelekan dan beranggapan untuk apa bahasa yang dipakai setiap hari dipelajari. Karena itu pendidik bahasa Indonesia di sekolah ditantang untuk memikirkan pertanyaan yang tepat, yaitu mengenai manusia dengan kualitas seperti apa yang ingin dimiliki oleh suatu lembaga pendidikan dan setelah mereka mempelajari bahasa Indonesia. Sehingga pendidik bahasa Indonesia perlu memikirkan nilai-nilai apa yang harus dikembangkan melalui pembelajaran bahasa Indonesia.

Nilai-nilai pembelajaran dan pengajaran secara umum pasti terjadi, namun kemungkinan besar para guru memiliki pemahaman terbatas tentang nilai-nilai apa yang harus diajarkan. Pertanyaan lain yang muncul adalah sampai sejauh mana guru bahasa Indonesia mengontrol nilai-nilai pembelajaran yang dibutuhkan siswa di era disrupsi. Apakah pembelajaran bahasa Indonesia dapat meningkatkan peluang siswa memperoleh nilai-nilai yang dibutuhkan di era disrupsi? Untuk menjawab pertanyaan-pertanyaan tersebut tulisan ini akan mengkaji tentang revolusi industri 4.0 sebagai bentuk penanaman karakter bangsa bahasa Indonesia dan nilai-nilai bahasa Indonesia dalam pembelajaran bahasa Indonesia di MI (madrasah ibtidaiyah).

\section{PEMBAHASAN}

\section{Era Disrupsi atau Revolusi Industri 4.0}

Banyak yang menganggap bahwa revolusi industri 4.0 adalah sebuah ancaman, masyarakat beranggapan di revolusi industri 4.0 tenaga manusia akan digantikan oleh robot, karena itulah akan ada banyak pengangguran. Automasi pada era revolusi industri 4.0 telah berdampak pada lebih dari 808 kerja dan lebih dari 2.000 jenis aktivitas pekerjaan serta 18 kemampuan yang dibutuhkan dalam setiap aktivitas pekerjaan yang tergabung dalam lima kelompok: kemampuan persepsi sensori, kemampuan kognitif, kemampuan alami dalam mengolah bahasa, kemampuan sosial dan emosional, dan kemampuan fisik. ${ }^{7}$ Setidaknya terdapat tiga keterampilan yang harus dikuasai tenaga kerja yaitu keterampilan menerapkan keahliannya, keterampilan berinteraksi dengan stakeholder dan keterampilan

${ }^{7}$ JC. Manyika, A Future that Works: Automation, Employment and Productivity (Amerika Serikat: McKinsey Global Universiy, 2017), 20 
Literasi Baru Sebagai Bentuk Penanaman... mengelola masa. Hal ini berimplikasi pada kebutuhan peningkatan proses pendidikan yang mampu membekali lulusan dengan keterampilan yang dibutuhkan pada revolusi industri 4.0.

Dalam mempersiapkan lulusan yang mampu memenuhi tantangan revolusi industri 4.0, pemerintah perlu memberi dukungan kepada sekolah untuk dapat melakukan transformasi pembelajaran dari model pembelajaran yang didominasi oleh inisiasi pendidik, menjadi pembelajaran menggunakan teknologi digital. Pendidikan harus dapat membimbing dan mengarahkan peserta didik untuk belajar sendiri, mereka harus bisa mengasah kemampuan yang mereka miliki hingga mereka dapat mengetahui potensi diri sendiri, mengembangkan potensi yang dimiliki melalui pengembangan pengetahuan dan keterampilan yang terkait, dan selanjutnya menciptakan sesuatu yang baru untuk diri sendiri ataupun masyarakat. Era revolusi industri 4.0 menuntut setiap orang untuk berinovasi agar dapat menghasilkan karya-karya yang dapat memaksimalkan potensi setiap individu dan memberi fasilitas serta akses yang sesuai dengan minat dan bakatnya dalam belajar.

Secara umum terdapat 18 kemampuan yang dibutuhkan dalam pengembangan revolusi industri 4.0 yaitu:

1. Kemampuan persepsi sensori.

2. Kemampuan mengambil informasi.

3. Kemampuan mengenali pola-pola dan kategori-kategori.

4. Kemampuan membangkitkan pola kategori baru.

5. Kemampuan memecahkan masalah.

6. Kemampuan memaksimalkan dan merencanakan.

7. Kreativitas.

8. Kemampuan mengartikulasikan dan menampilkan output.

9. Kemampuan berkoordinasi dengan berbagai pihak.

10. Kemampuan menggunakan bahasa untuk mengungkapkan gagasan.

11. Kemampuan menggunakan bahasa untuk memahami gagasan.

12. Kemampuan penginderaan sosial.

13. Kemampuan membuat pertimbangan sosial dan emosional.

14. Kemampuan menghasilkan output emosional dan sosial. 58 | Jurnal Auladuna 


\section{Siti Mutmainah}

15. Kemampuan motorik halus dan ketangkasan.

16. Kemampuan motorik kasar.

17. Kemampuan navigasi.

18. Kemampuan mobilitas. ${ }^{8}$

Pembelajaran harus mampu mengintegrasikan ke-18 kemampuan tersebut dalam kegiatan pembelajaran, untuk itu perlu dirancang skenario pembelajaran yang dapat menciptakan lingkungan dan situasi agar peserta didik dapat memunculkan potensi dan kemampuan diri sendiri, serta mengasah kemampuan yang dimiliki untuk menciptakan pengetahuan berkaitan dengan bidang ilmu yang ditekuni dan bidang pekerjaan yang digeluti nantinya.

\section{Tantangan Era Revolusi Industri 4.0}

Revolusi industri 4.0 disebut juga sebagai revolusi digital dan era disrupsi teknologi. Tantangan-tantangan industri 4.0 menurut Muhammad Yahya, antara lain: pertama, keamanan teknologi informasi; kedua, keandalan dan stabilitas mesin produksi; ketiga, kurangnya keterampilan yang memadai; keempat, keengganan berubah pemangku kepentingan; kelima, hilangnya banyak pekerjaan karena berubah menjadi otomatisasi.

Tantangan industri 4.0 menurut Yahya juga meliputi beberapa hal: pertama, kesiapan industri; kedua, tenaga kerja terpercaya; ketiga, kemudahan pengaturan sosial budaya; keempat, diversifikasi dan penciptaan lapangan kerja serta peluang. Industri 4.0 yaitu inovasi ekosistem berbasis industri yang kompetitif, investasi pada teknologi dan integrasi usaha kecil menengah UKM dan kewirausahaan. Tantangan era revolusi industri 4.0 begitu kompleks dan tidak hanya terjadi pada dunia kerja serta digital saja, namun juga dalam dunia pendidikan. Saat ini dunia pendidikan pun sudah serba teknologi, tidak seperti sebelumnya yang cukup menggunakan sistem manual, misalkan saja e-library (perpustakaan digital), e-learning (pembelajaran digital), e-book (buku online) dan lainnya.

Pemanfaatan teknologi informasi dan komunikasi dalam pembelajaran, seperti penggunaan berbagai aplikasi digital e-book, website, dan gaya belajar digital lainnya berdampak positif. Dampak tersebut tidak hanya dari segi minat belajar, namun juga dari hasil belajar siswa yang semakin meningkat. Dengan demikian dapat disimpulkan bahwa

${ }^{8}$ S. Yamnoon, Education 4.0 Teaching and Learning in 21 Century Lobbury (Thailand: Thepsatri Rhajabat University, 2018), 79 
Literasi Baru Sebagai Bentuk Penanaman... tantangan di era revolusi industri 4.0 sangat kompleks, terutama dalam dunia pendidikan. Pembangunan era revolusi industri 4.0 ditandai dengan masifnya perkembangan digital dan lainnya, meskipun tidak pada semua aspek, setidaknya lembaga pendidikan dapat fokus pada penguatan literasi baru.

\section{Peran Pendidik di Era Revolusi Industri 4.0}

Perubahan zaman yang begitu cepat mengharuskan para pendidik berinovasi. Karakteristik model dari industri 4.0 adalah kombinasi dari beberapa perkembangan teknologi terbaru, seperti sistem cyber fisik, teknologi informasi dan komunikasi, jaringan komunikasi data cloud computing, pemodelan virtualisasi simulasi, serta peralatan untuk kemudahan interaksi manusia melalui komputer. ${ }^{9}$ Di era revolusi industri 4.0 semua serba terdistribusi. Pendidik harus memiliki kemampuan literasi baru dengan aspek literasi data, literasi teknologi dan literasi humanisme/ SDM. Pendidik juga harus menyelaraskan kompetensinya dengan kemajuan teknologi.

Pendidik sangat perlu memahami tiga kunci kemajuan pendidikan, yaitu kompetensi, karakter dan literasi, yang mana melalui ketiga hal ini pendidikan di Indonesia akan melejit. ${ }^{10}$ Inti dari era revolusi industri 4.0 yaitu manusia berorientasi pada teknologi dunia maya, big data dan lainnya. Manusia harus dapat mengatasi semua permasalahan yang kompleks di era ini, salah satu caranya dengan menanamkan keterampilan dan kemampuan yang menjadi tugas besar pendidik.

\section{Revitalisasi Sistem Pembelajaran di Era 4.0}

Tantangan terbesar dari era revolusi industri 4.0 adalah meningkatnya jumlah pengangguran. Ancaman semakin banyaknya pengangguran tersebut membuat pemerintah merespon dengan meningkatkan kualitas sumber daya manusia melalui pendidikan dengan berbagai kebijakan, salah satu kebijakan tersebut adalah revitalisasi pendidikan kejuruan Indonesia. Revitalisasi sistem pembelajaran meliputi:

1. Kurikulum dan pendidikan karakter.

\footnotetext{
${ }^{9}$ Rahman Fauzan, Karakteristik Model dan Analisa Peluang Tantangan Industri 4.0 ( Jurnal Phasti: Volume 04 Nomor 1 April 2018), 1

${ }^{10}$ Dian Marta Wijayanti, Guru Zaman Now: Guruku Sahabatku (Semarang: Formasi, 2017), 7-8 60 | Jurnal Auladuna
} 


\section{Siti Mutmainah}

2. Bahan pembelajaran berbasis teknologi informasi dan komunikasi.

3. Kewirausahaan.

4. Penyelarasan.

5. Evaluasi.

Satuan pendidikan meliputi: (1) unit sekolah baru dan ruang kelas baru; (2) ruang belajar lainnya; (30) rehabilitasi ruang kelas; (4) asrama siswa dan guru; (5) peralatan dan; (6) manajemen dan kultur sekolah. Elemen peserta didik meliputi: pemberian beasiswa dan pengembangan bakat minat. Elemen pendidik dan tenaga kependidikan meliputi: (1) penyediaan; (2) distribusi; (3) kualifikasi sertifikasi; (5) pelatihan (6) karir dan kesejahteraan; (7) penghargaan dan perlindungan.

Keempat elemen yang disebutkan di atas membutuhkan gerakan pembaharuan. Salah satu gerakan pembaruan tersebut adalah gerakan literasi baru. Gerakan literasi baru di antaranya fokus pada literasi digital, literasi teknologi dan literasi manusia. Keterampilanketerampilan tersebut sangat dibutuhkan untuk masa depan di era industri 4.0. Literasi baru diharapkan dapat menciptakan lulusan yang kompetitif, karena literasi baru bertujuan untuk meningkatkan kemampuan membaca, menganalisis dan menggunakan informasi di dunia digital atau big data. Literasi teknologi bertujuan untuk memberikan pemahaman dan pengaplikasian teknologi, sedangkan bagi manusia diarahkan untuk dapat meningkatkan kemampuan berkomunikasi dan penguasaan ilmu.

Adaptasi gerakan literasi baru dalam dunia pendidikan dapat diintegrasikan dengan melakukan penyesuaian kurikulum dan sistem pembelajaran. Trilling dan Fadel menyebutkan bahwa pembelajaran abad 21 berorientasi pada gaya hidup digital sebagai alat berpikir pada penelitian dan pembelajaran serta cara kerja pengetahuan. Seluruh bentuk kecakapan dan keterampilan di abad 21 dan era industri 4.0 yang dibutuhkan harus diintegrasikan ke dalam semua elemen, terutama pendidikan.

\section{Literasi Baru pada Madrasah Ibtidaiyah}

Madrasah Ibtidaiyah merupakan jenjang lembaga pendidikan fondasi pertama untuk mendapatkan kecerdasan intelektual, spiritual dan emosional. Terdapat kompetensi literasi yang harus disesuaikan dengan spirit zaman untuk mencapai aspek kecerdasan tersebut. Dalam hal ini, guru harus segera merespon perubahan zaman yang begitu cepat. Hanya 
Literasi Baru Sebagai Bentuk Penanaman... guru yang mampu membawa peralihan zaman dan yang dapat menjawab tantangan revolusi industri 4.0.

Literasi di dunia pendidikan secara resmi muncul melalui program pemerintah. Program literasi saat ini pembelajaran masih berkutat pada aspek membaca. Padahal, hal ini masih belum cukup, karena mengharuskan kemampuan menulis dan membaca. Kemdikbud mengembangkan Gerakan Literasi Sekolah (GLS) dalam rangka mengembangkan sekolah sebagai organisasi pembelajaran. GLS merupakan upaya yang melibatkan semua komponen sekolah termasuk guru, peserta didik, orang tua/ wali murid dan masyarakat. GLS memperkuat penumbuhan budi pekerti, seperti tertuang dalam Peraturan Menteri Pendidikan dan Kebudayaan Nomor 23 Tahun 2015. Salah satu kegiatan di dalam gerakan ini berupa kegiatan 15 menit membaca buku non-pelajaran sebelum waktu belajar dimulai. ${ }^{11}$

Faktanya GLS hanya mengacu pada kemampuan literasi lama dan tidak berkutat pada literasi baru. Seharusnya untuk menjawab era revolusi industri 4.0, kompetensi literasi baru harus dikuatkan, meskipun masih berada di jenjang MI/ SD. Hal tersebut dapat dimulai melalui pendekatan sederhana yang capaian pembelajarannya relevan dengan literasi baru. Dalam hal ini perlu adanya penguatan literasi baru yang dapat dilakukan dengan beberapa pendekatan. Pertama, anak-anak harus diajarkan memahami data baik kualitatif, kuantitatif, maupun informasi-informasi yang didapat dalam pembelajaran agar siswa memahami literasi data. Kedua, literasi teknologi bergantung pada kemampuan manusia Indonesia yang dapat mengoperasikannya dengan meningkatkan kemampuan penggunaan internet secara optimal, memperluas akses, dan meningkatkan proteksi cyber security. Ketiga, literasi Sumber Daya Manusia yang menekankan pada penguatan keunggulan komunikasi dan desain. Anak-anak di era cyber juga tidak boleh tercerabut dari akarnya, mereka harus bisa berkomunikasi bahasa asing tanpa harus meninggalkan bahasa nasional. ${ }^{12}$

Dari penjabaran diatas dapat disimpulkan, literasi baru merupakan literasi untuk mendapatkan pengetahuan dan menghadapi tantangan "kecerabutan" dengan aspek

\footnotetext{
${ }^{11}$ Wiedarti Pangesti dkk, Desain Industri akan Literasi Sekolah Jakarta (Direktorat Jenderal Pendidikan Dasar dan Menengah) (Kementerian Pendidikan dan Kebudayaan: 2016), 1-2

${ }^{12}$ Ibda Hamidulloh, Penguatan Gernas Baku Dalam Keluarga (Opini Satelit Post., 10 April 2018) 62 | Jurnal Auladuna
} 


\section{Siti Mutmainah}

kompetensi literasi data, teknologi, dan humanisme. Literasi baru yang harus diaplikasikan di madrasah ibtidaiyah dan sekolah dasar yaitu dengan menerapkan tradisi pilar literasi: baca, tulis, arsip. Guru madrasah ibtidaiyah harus mampu menguatkan pembelajaran literasi abad 21 dengan capaian pembelajaran yang kreatif, berpikir kritis, komunikatif dan kolaboratif.

\section{Karakter Bangsa}

Era disrupsi menuntut perubahan kompetensi yang ditandai dengan pemanfaatan teknologi informasi dan komunikasi dalam semua hal, termasuk pembelajaran dalam menyongsong kemajuan dan tuntutan hidup. Generasi muda di era disrupsi harus memiliki kecakapan berpikir dan belajar, kecakapan berpikir kritis, memecahkan masalah dan berkolaborasi menjadi kompetensi penting dalam memasuki era disrupsi. Rasa kebangsaan akan paham kebangsaan dan semangat kebangsaan merupakan unsur utama dalam karakter bangsa. ${ }^{13}$ Poin utama dari kebangsaan adalah kesatuan, sedangkan semangat kebangsaan merupakan sinergi dari rasa kebangsaan dan paham kebangsaan. Semangat ini sangat diperlukan dalam rangka mencapai cita-cita bangsa dan tujuan nasional, ${ }^{14}$ untuk itu setiap siswa di Indonesia perlu ditingkatkan semangat NKRI harga mati.

Seluruh warga Indonesia perlu mengembangkan karakter bangsa dengan baik. Pengembangan karakter bangsa yang dimaksud yaitu pengembangan kemandirian (selfreliance), martabat internasional (bargaining position), persatuan nasional (national unity) dan demokrasi (democracy). Indonesia merupakan negara demokrasi, di mana setiap warga negara terlibat dalam proses politik dan pengambilan keputusan. Kesejahteraan dan kemakmuran negara bisa dicapai jika demokrasi harus menaati kesepakatan oleh seluruh warga negara Indonesia. Kesepakatan itu meliputi: pertama, kesepakatan mengenai tujuan dan cita-cita bersama (the general goal of society). Kedua, kesepakatan aturan hukum (the rule of law) sebagai dasar penyelenggaraan negara. Ketiga, kesepakatan tentang bentukbentuk lembaga negara beserta prosedur ketatanegaraan (the form of institution and the prosedur).

\footnotetext{
${ }^{13}$ Moetodjib, Refleksi dan Aksi Kebangsaan di Tengah Modernitas Global (Yogyakarta: Fakultas Filsafat UGM, 2010), 13

${ }^{14}$ I. Sujadi, Mengaplikasikan Matematika Sebagai Pilar Pengembangan Karakter Bangsa (Makalah dipresentasikan pada Seminar Nasional Pengembangan Nilai-Nilai dan Aplikasi dalam Dunia Matematika Sebagai Pilar Pembangunan Karakter Bangsa (Semarang: Universitas Negeri Semarang, 2011)
} 
Literasi Baru Sebagai Bentuk Penanaman...

Terdapat banyak nilai karakter bangsa dalam kurikulum sekolah sebagaimana tercantum pada Permendikbud Nomor 21 Tahun 2016. Nilai-nilai karakter bangsa tertuang dalam kompetensi sikap spiritual dan sikap sosial. ${ }^{15}$ Nilai tersebut antara lain jujur, toleransi, disiplin, kerja keras, kreatif, mandiri, demokratis, rasa ingin tahu, semangat kebangsaan, cinta tanah air, menghargai prestasi, komunikatif, cinta damai, gemar membaca, peduli lingkungan, peduli sosial, konsisten, taat asas dan tanggung jawab.

\section{Pengertian Nilai (Value)}

Kamus Besar Bahasa Indonesia mengartikan nilai sebagai sifat-sifat yang penting bagi kemanusiaan. Nilai adalah bagian tak terpisahkan dari proses pendidikan di semua tingkatan dari sistem kelembagaan tingkat makro yaitu melalui pengembangan kurikulum dan manajemen, maupun tingkat mikro yaitu interaksi kelas. ${ }^{16}$ Nilai memiliki peranan yang sangat penting dalam membangun rasa identitas pribadi dan sosial siswa. Nilai yang terdapat di kelas terkait dengan identitas pedagogi guru. Pedagogi adalah ilmu atau seni menjadi seorang guru. Pedagogi dapat diartikan sebagai strategi pembelajaran atau gaya mengajar. Strategi mengajar diterapkan dan dipengaruhi oleh latar belakang pengetahuan dan pengalaman guru, situasi pribadi, lingkungan, serta tujuan pembelajaran yang dirumuskan oleh guru tersebut.

Penanaman pendidikan karakter pada peserta didik dapat dilakukan melalui pembelajaran bahasa Indonesia. Nilai-nilai karakter dalam pembelajaran bahasa Indonesia dapat terwujud apabila guru menguasai keterampilan berbahasa sesuai dengan fungsinya. Hal ini berbeda dengan apa yang ada di lapangan, guru hanya mengajarkan pembelajaran bahasa Indonesia yang ditekankan pada teori kebahasaan. Pengajaran bahasa Indonesia adalah pengajaran keterampilan berbahasa, bukan pengajaran tentang kebahasaan. Teoriteori bahasanya sebagai pendukung atau penjelas dalam konteks, yaitu yang berkaitan dengan keterampilan tertentu yang telah diajarkan. ${ }^{17}$

\footnotetext{
${ }^{15}$ Kemdikbud, Permendikbud Nomor 21 Tahun 2016 tentang Standar Isi Pendidikan Dasar dan Menengah (Jakarta: Kemdikbud, 2016)

${ }^{16}$ Sudjadi, Perolehan Nilai dalam Pembelajaran Matematika (Makalah disampaikan dalam Seminar Nasional Pendidikan Matematika FKIP UNS) (Yogyakarta: Universitas Sebelas Maret, 2012)

${ }^{17}$ Slamet dkk, Dasar-Dasar Pembelajaran Bahasa dan Sastra Indonesia di Sekolah Dasar (LPPM UNS dan UPT Surakarta, 2007), 6

64 | Jurnal Auladuna
} 


\section{Siti Mutmainah}

Pembelajaran bahasa Indonesia sebagaimana yang dituangkan dalam Standar Isi mata pelajaran bahasa Indonesia Permendiknas yang menekankan sebagai berikut: berkomunikasi secara efektif dan efisien sesuai dengan etika yang berlaku baik secara lisan maupun tulisan; menghargai dan bangga menggunakan bahasa Indonesia sebagai bahasa persatuan dan bahasa negara; memahami bahasa Indonesia dan menggunakannya dengan tepat serta kreatif untuk berbagai tujuan; menggunakan bahasa Indonesia untuk meningkatkan kemampuan intelektual serta kematangan emosional dan sosial; menikmati dan memanfaatkan karya sastra untuk memperluas wawasan, memperluas budi pekerti serta meningkatkan pengetahuan dan kemampuan berbahasa; menghargai dan membanggakan sastra Indonesia sebagai khazanah budaya dan intelektual manusia Indonesia.

Peran pendidikan sangat menentukan terlaksananya kedudukan dan fungsi bahasa Indonesia. Guru harus mengajarkan pembelajaran bahasa dengan menanamkan nilai-nilai karakter terhadap peserta didik. Peserta didik harus mengetahui penggunaan bahasa Indonesia, mencerminkan nilai-nilai sosial budaya luhur bangsa Indonesia. Penggunaan bahasa Indonesia dapat digunakan untuk mengetahui perangai sifat dan watak pemakainya. Maka daripada itu pendidik dan para siswa harus menjaganya agar jangan sampai ciri kepribadian pemakai bahasa tidak mencerminkan nilai-nilai luhur sebagai identitas bangsa.

Nilai pembelajaran bahasa Indonesia harus ada pada keterampilan berbahasa yaitu mendengar, berbicara, membaca dan menulis. Masing-masing keterampilan tersebut saling berkaitan, untuk itu guru harus mengintegrasikan nilai-nilai karakter sosial budaya luhur bangsa Indonesia melalui pembelajaran bahasa Indonesia. Kesimpulannya penanaman nilai-nilai karakter dapat dimulai dengan memberikan pemahaman kepada peserta didik, bahwa bahasa Indonesia merupakan jati diri bangsa yang harus dipelihara dan dipertahankan. Bahasa Indonesia menjadi ciri budaya yang dapat diandalkan di tengahtengah pergaulan antar bangsa. Pada era disrupsi saat ini, peserta didik juga diharapkan berkembang dalam hal intelektual sosial dan emosional, serta mampu mengenal budayanya dan budaya orang lain sebagai wujud dari sebuah karakter.

\section{Penerapan Teknologi Informasi dalam Pembelajaran Bahasa Indonesia MI}

Salah satu contoh penerapan teknologi informasi ke dalam pembelajaran bahasa Indonesia, misalkan saja dalam pembelajaran sastra anak-anak bisa diajarkan dengan 
Literasi Baru Sebagai Bentuk Penanaman... melihat langsung contoh pemodelan pembacaan puisi melalui YouTube. Pemodelan yang melihat langsung cara pembacaan puisi yang benar dari profesional di YouTube, maka siswa akan lebih mudah meniru. Contoh lain misalnya dalam bermain peran atau drama, siswa dapat melihat pemodelan melalui YouTube atau media teknologi lain yang tentunya pemodelan penampilan drama yang bagus dan benar dari kalangan profesional. Selain itu siswa juga bisa diajarkan bagaimana cara agar penampilan sastra mereka baik puisi atau pun drama dapat dipublikasikan melalui media sosial. Contoh simpelnya melalui YouTube, agar penampilan mereka yang baik dapat dijadikan model oleh masyarakat Indonesia.

Contoh pemodelan melalui menonton dari alat teknologi tersebut tidak hanya dalam pembelajaran sastra, tetapi juga pada ranah pembelajaran bahasa Indonesia lainnya. Misalkan pemodelan pembacaan berita, pidato, ataupun orasi. Hal ini memerlukan kemampuan dan keterampilan guru dalam memilih dan mengoperasikan alat teknologi informasi. Pada dasarnya contoh penggunaan alat teknologi informasi dalam pembelajaran bahasa Indonesia sangatlah luas. Saat ini banyak ditemukan aplikasi baru yang dapat mendukung semua pembelajaran di madrasah ibtidaiyah atau sekolah dasar, termasuk pembelajaran bahasa Indonesia.

\section{PENUTUP}

\section{Simpulan}

Era disrupsi merupakan era terjadinya perubahan besar-besaran dalam semua bidang. Dampak dari teknologi modern agar bisa menghadapi tantangan di era disrupsi, semua warga negara Indonesia membutuhkan karakter bangsa agar tidak mudah goyah. Karakter bangsa yang harus dikembangkan yaitu pengembangan kemandirian (self-reliance), martabat internasional (bergaining position), persatuan nasional (nasional united) dan demokrasi (democracy). Dalam karakter bangsa terdapat banyak nilai di dalamnya, antara lain: jujur, toleransi, disiplin, kerja keras, kreatif, mandiri, demokratis, rasa ingin tahu, semangat kebangsaan, cinta tanah air, menghargai prestasi, bersahabat, cinta damai, gemar membaca, peduli lingkungan, peduli sosial, konsisten, taat asas dan tanggung jawab.

Nilai-nilai tersebut dapat diperoleh dari nilai pendidikan secara umum, termasuk juga dalam pembelajaran bahasa Indonesia. Nilai-nilai tersebut diharapkan tidak hanya didapat dari pembelajaran bahasa Indonesia yang dilakukan. Tetapi juga diperoleh dari 66 | Jurnal Auladuna 


\section{Siti Mutmainah}

pembelajaran yang direncanakan oleh guru agar siswa memperoleh nilai dalam pembelajaran bahasa Indonesia. Guru bahasa Indonesia harus memahami hakikat bahasa Indonesia dan nilai-nilai yang terkandung di dalamnya, dapat melakukan pembelajaran yang mendidik, serta memahami filosofi bagaimana pembelajaran bahasa Indonesia dilakukan.

Pembelajaran bahasa Indonesia harus dapat menerapkan prinsip-prinsip pembelajaran sebagaimana tertuang dalam Standar Proses pembelajaran kurikulum yang berlaku. Keberadaan karakter bangsa yang kuat menjadikan peserta didik mampu mempertahankan hidupnya pada saat ini dan mampu menghadapi tantangan hidup di masa depan.

\section{DAFTAR PUSTAKA}

Ahmadi, Farid dan Hamidulloh Ibda. Media Literasi Sekolah Teori dan Praktik. Semarang: CV Pilar Nusantara, 2018.

Fauzan, Rahman. Karakteristik Model dan Analisa Peluang Tantangan Industri 4.0. Jurnal Phasti Vol. 04 Nomor 1 April 2018.

Ghufran, Ali Ibrahim dkk. Peta Jalan Gerakan Literasi Nasional. Jakarta: Kemdikbud, 2017.

Hamidulloh, Ibda. Penguatan Gernas Baku Dalam Keluarga. Opini Satelit Post. 10 April 2018.

Kemendikbud. Permendikbud Nomor 21 Tahun 2016 tentang Standar Isi Pendidikan Dasar dan Menengah. Jakarta: Kemendikbud, 2016.

Undang-undang No 20 tahun 2003 tentang Sistem Pendidikan Nasional. Jakarta: Kemendikbud, 2003.

Manyika, JC. A Future that Works: Automation, Employment and Productivity. Amerika Serikat: McKinsey Global Universiy, 2017.

Moetodjib. Refleksi dan Aksi Kebangsaan di Tengah Modernitas Global. Yogyakarta: Fakultas Filsafat UGM, 2010. 
Literasi Baru Sebagai Bentuk Penanaman...

Pangesti, Wiedarti dkk. Desain Industri akan Literasi Sekolah. Jakarta: Direktorat Jenderal Pendidikan Dasar dan Menengah, 2016.

Slamet, dkk. Dasar-dasar Pembelajaran Bahasa dan Sastra Indonesia di Sekolah Dasar. Surakarta: LPPM UNS dan UPT, 2007.

Sudjadi. Perolehan Nilai dalam Pembelajaran Matematika (Makalah disampaikan dalam Seminar Nasional Pendidikan Matematika FKIP UNS). Yogyakarta: Universitas Sebelas Maret, 2012.

Sujadi, I. Menumbuhkan Karakter Bangsa dengan Mengimplementasikan Mathematics Value dalam Pembelajaran. Pontianak: IKIP PGRI Pontianak, 2017. . Mengaplikasikan Matematika sebagai Pilar Pengembangan Karakter Bangsa (Makalah dipresentasikan pada Seminar Nasional Pengembangan Nilai-nilai dan Aplikasi dalam Dunia Matematika sebagai Pilar Pembangunan Karakter Bangsa. Semarang: Universitas Negeri Semarang, 2011.

Wijayanti, Dian Marta. Guru Zaman Now: Guruku Sahabatku. Semarang: Formasi, 2017.

Yahya, Muhammad. Era Industri 4.0: Tantangan dan Peluang Perkembangan Pendidikan Kejuruan Indonesia (Naskah Pidato Pengukuhan Guru Besar disampaikan pada Sidang Terbuka Luar Biasa Senat Universitas Negeri Makassar). 14 Maret 2018.

Yamnoon, S. Education 4.0: Teaching and Learning in 21 Century Lobbury. Thailand: Thepsatri Rhajabat University, 2018.

68 | Jurnal Auladuna 